Original Research Article

\title{
Role of antihypertensives drugs on proteinuria in patients with chronic kidney disease and hypertension
}

\author{
Ritu Bala ${ }^{1 *}$, Harminder Singh ${ }^{1}$, Rupali $^{2}$, Kuhu Verma ${ }^{1}$
}

\author{
${ }^{1}$ Department of Pharmacology, \\ ${ }^{2}$ Department of Community \\ Medicine, Guru Gobind Singh \\ Medical College, Faridkot, \\ Punjab, India
}

Received: 15 August 2017

Accepted: 06 September 2017

*Correspondence to:

Dr. Ritu Bala,

Email: reetgro@gmail.com

Copyright: (C) the author(s), publisher and licensee Medip Academy. This is an openaccess article distributed under the terms of the Creative Commons Attribution NonCommercial License, which permits unrestricted noncommercial use, distribution, and reproduction in any medium, provided the original work is properly cited.

\begin{abstract}
Background: Hypertension is the most prevalent cardiovascular disease and the relevant data suggest that the burden, risk factors and co-morbidities associated with the essential hypertension is increasing with every passing day. It is one of the major chronic diseases resulting in high mortality and morbidity in today's world. Aim: The aim of the study was to compare effects of cilnidipine and amlodipine on the blood pressure (BP), heart rate and proteinuria among patients of hypertension with chronic kidney disease.

Methods: 100 patients were included in this study. Patients were randomly assigned into two groups Group A and Group B (50 each). Group A: Patients received Cilnidipine (5-10mg/day). Group B: Patients received amlodipine (5$10 \mathrm{mg} /$ day).

Results: No significant difference in SBP, DBP, MBP and proteinuria while comparing both the groups of patients taking cilnidipine and amlodipine at baseline i.e. 0 to 12 week, 12 to 24 weeks and 0 to 24 weeks. Cilnidipine caused decrease in HR 0 to 12 week (p value 0.001), 12 to 24 weeks (p value 0.001 ) and 0 to 24 weeks ( $\mathrm{p}$ value 0.0001 ). Amlodipine had increased heart rate from baseline to 12 weeks ( $\mathrm{p}$ value 0.0001 ), 12 to 24 weeks ( $\mathrm{p}$ value 0.051 ) and 0 to 24 weeks ( $\mathrm{p}$ value 0.001 ). No significant difference was seen in any biochemical readings.

Conclusions: There was a significant change in all the parameters including BP, heart rate, proteinuria and other biochemical tests when they compared within the group but no significant difference while comparing both the groups.
\end{abstract}

Keywords: Amlodipine, Cilnidipine, Hypertension, Proteinuria

\section{INTRODUCTION}

Hypertension is one of the major chronic diseases resulting in high mortality and morbidity in today's world. Socioeconomic, behavioral, nutritional and public health issues also lead to increase in cardiovascular diseases (CVD) throughout the world. The prevalence of hypertension increases with advancing age, about $50 \%$ of people between the ages of 60 and 69 years old and the prevalence is further increased beyond age 70 years. ${ }^{1}$ So, it characterizes a group of patients whose risk of hypertension-related cardiovascular disease is high enough to merit medical attention. Actually, the risk of both fatal and nonfatal cardiovascular disease in adults is lowest with systolic blood pressures of $<120 \mathrm{~mm} \mathrm{Hg}$ and diastolic $\mathrm{BP}<80 \mathrm{~mm} \mathrm{Hg}$; these risks increase progressively with higher systolic and diastolic blood pressures. $^{2}$

Hypertension is common in chronic renal disease and is a risk factor for the faster progression of renal damage. Reduction of blood pressure (BP) is an efficient way of preventing or slowing the progression of this damage. The pathogenesis of hypertensive renal damage involves mediators from various extracellular systems, including the rennin -angiotensin system (RAS). Proteinuria, which occurs as a consequence of elevated intra-glomerular 
pressure, is also directly nephrotoxic. Reduction of proteinuria is associated with delayed progression of chronic kidney disease. Increased blood pressure has a major role in the development of proteinuria in patients with either diabetic or non-diabetic kidney disease, and all recent guidelines recommend a blood pressure goal less than $130 / 80 \mathrm{~mm} \mathrm{Hg}$ in patients with proteinuria to achieve maximal renal and cardiovascular protection. Proteinuria is without symptoms and may be a sign of silent kidney disease or damage. Hypertension is classified as either primary (essential) hypertension or secondary hypertension. Primary hypertension is the most common form of hypertension, accounting for $90-95 \%$ of all cases of hypertension. ${ }^{2}$ Secondary hypertension results from an identifiable cause. Renal disease is the most common cause of secondary hypertension.

The prevalence of hypertension in the last six decades has increased from $2 \%$ to $25 \%$ among urban residents, Ministry of Health and Family Welfare, Government of India, the overall prevalence of hypertension in India by 2020 will be $159.46 / 1000$ population. ${ }^{3}$ Hypertension is a major risk factor for myocardial infarction, congestive heart failure, stroke and end-stage renal disease. ${ }^{4}$ JNC-8 classification for hypertension guidelines as given in Table 1.5,6

Table 1: The JNC-8 classification.,

\begin{tabular}{|lll|}
\hline Classification & $\begin{array}{l}\text { Systolic BP } \\
(\mathbf{m m} \mathbf{H g})\end{array}$ & $\begin{array}{l}\text { Diastolic BP } \\
(\mathbf{m m} \mathbf{H g})\end{array}$ \\
\hline Normal & $<120$ & And $<80$ \\
\hline Pre-hypertension & $120-139$ & Or $80-89$ \\
\hline Stage 1 hypertension & $140-159$ & Or $90-99$ \\
\hline Stage 2 hypertension & $>160$ & Or $>100$ \\
\hline
\end{tabular}

Calcium channel blockers are widely used as first line antihypertensive drugs in hypertension. In this study, we have compared two Calcium channel blockers i.e. Cilnidipine and Amlodipine in patients of hypertension. ${ }^{4}$

\section{Cilnidipine}

Cilnidipine is a new unique dihydro-pyridine derivative, fourth generation calcium channel blocker-type $\mathrm{Ca}^{2+}$ channel blocker with an inhibitory action on the sympathetic N-type $\mathrm{Ca}^{2+}$ channels, $\mathrm{Ca}^{2+}$ channels are ordinarily activated by membrane depolarization in the vascular cells or sympathetic neurons, leading to vascular contraction or neurotransmitter releases. Cilnidipine dilates afferent and efferent arterioles in the kidney and decreases glomerular capillary pressure thereby reducing proteinuria and impairing glomerulosclerosis and arteriolar lesions. $^{7}$

\section{Amlodipine}

Amlodipine is an L- type calcium channel blocker. It is a third generation CCB. The two most important actions of
Amlodipine are smooth muscle relaxation and negative ionotropic, chronotropic, and dromotropic actions on the heart. It has been shown to release NO from endothelium and inhibit cAMP - phosphodiesterase resulting in raised smooth muscle cGMP. Released endothelial NO may exert anti atherosclerotic action. It is a long acting dihydropyridine calcium antagonist that inhibits transmembrane influx of calcium ions into vascular smooth muscle and cardiac muscle. ${ }^{8}$

\section{METHODS}

This study was an open labelled randomized prospective study. The study was conducted in Medicine Department OPD of a tertiary care centre in Faridkot, Punjab.

\section{Study population}

100 patients were included for study purpose. They were randomly assigned into two groups $A$ and $B$ (50 each). In Group A, 48 patients could complete the study while in Group B only 46 completed the study.

- Group A: patients in this group received Cilnidipine (5-10mg/day).

- Group B: patients received Amlodipine (5$10 \mathrm{mg} /$ day).

Both the drugs started with a low dose and then doses titrated to achieve the desired BP $(<140 / 90 \mathrm{mmHg})$.

The patients were assigned to the study after their written informed consent. The ethical approval of the study was taken from institutional ethical committee before commencement of the study.

\section{Inclusion criteria}

- Patients with hypertension with chronic kidney disease.

- $\quad$ Patients in age group of 30 -70 year.

- Patients who gave their informed written consent for the study.

\section{Exclusion criteria}

- $\quad$ Patients with pre-eclampsia and eclampsia.

- Pregnant and Lactating females.

- $\quad$ Patients with thyroid disorders.

- $\quad$ Patients who are already on the drugs like ARBs and ACE inhibitors.

Diagnosis of hypertension was done on the basis of clinical history, complete physical examination and routine blood tests as well as special tests like 24 hour urine test for protein. Blood tests like fasting blood sugar, renal function tests, liver function tests, lipid profile, serum uric acid, serum electrolytes, urine routine, 24 hour urinary protein and ECG of all these patients was done prior to enrollment in the study groups. Investigations were undertaken at the 
beginning of therapy i.e. at 0 day ( $1^{\text {st }}$ visit) then at, 12 weeks and then finally at 24 weeks. Then after diagnosing the patients were randomly recruited into 2 groups one was given Cilnidipine 5-10mg and other was given amlodipine $5-10 \mathrm{mg}$. Follow up was done on $12^{\text {th }}$ week and $24^{\text {th }}$ week where BP was monitored, along with other investigations were done. Investigations were undertaken at the beginning of therapy i.e. at 0 day (1st visit) then at, 12 weeks and then finally at 24 weeks.

Data for the mentioned parameters were statistically analyzed for their significance using the Student $t$ test (paired and unpaired) and $\mathrm{p}$ values were calculated to evaluate the level of significance. A difference of less than i.e. $p<0.05$ is considered as significant.

\section{RESULTS}

A total of 100 patients were studied during the period of 1 Among 100 patients, in group A out of 50, 2 were non responsive. 25 males and 23 females participated in the study. And in Group B among 50, 4 patients were non responsive rate of so didn't participate in the study. Total of 94 patients participated in our study (Table 2).

\section{Table 2: Sex wise distribution of patients in Group A} and $B$.

\begin{tabular}{|lllll|}
\hline Sex & \multicolumn{2}{l}{ Group A } & \multicolumn{2}{l|}{ Group B } \\
\hline Nole & No. & \% age & No. & \% \\
\hline Female & 25 & $52.09 \%$ & 24 & $52.18 \%$ \\
\hline
\end{tabular}

Intra group comparison of patients on Cilnidipine at 0 weeks, 12 weeks and 24 weeks was done. All the investigations done were compared. (Table 3). The results show the significant difference in SBP, DBP, MBP, HR and proteinuria after this drug ( $p$ value $<0.05$ ). All other values of tests like serum- cholesterol, serum-triglycerides, serum-HDL, SGPT, SGOT were insignificant ( $\mathrm{p}$ value $>0.05)$.

Table 3: Intragroup comparison of group A (Cilnidipine): at baseline (0 week), 12 weeks and 24 weeks.

\begin{tabular}{|lllll|}
\hline Parameters & $\begin{array}{l}\text { Baseline } \\
\text { (0 week) } \\
\text { Mean } \pm \text { SD }\end{array}$ & $\begin{array}{l}\text { 12 weeks } \\
\text { Mean } \pm \text { SD }\end{array}$ & $\begin{array}{l}\text { 24 weeks } \\
\text { Mean } \pm \text { SD }\end{array}$ & $\begin{array}{c}\text { p } \\
\text { value }\end{array}$ \\
\hline $\begin{array}{l}\text { SBP } \\
(\mathrm{mmHg})\end{array}$ & $152.73 \pm 17.9$ & $150.52 \pm 17.7$ & $140.86 \pm 12.6$ & 0.001 \\
\hline $\begin{array}{l}\mathrm{DBP} \\
(\mathrm{mmHg})\end{array}$ & $100.56 \pm 7.84$ & $91.91 \pm 7.78$ & $87.65 \pm 6.08$ & 0.001 \\
\hline $\begin{array}{l}\mathrm{MBP} \\
(\mathrm{mmHg})\end{array}$ & $118.1 \pm 7.56$ & $111.28 \pm 9.93$ & $105.39 \pm 6.6$ & 0.001 \\
\hline $\begin{array}{l}\text { Mean HR } \\
(\mathrm{mmHg})\end{array}$ & $78.60 \pm 3.29$ & $80.03 \pm 2.78$ & $72.07 \pm 3.28$ & 0.001 \\
\hline $\begin{array}{l}\text { Proteinuria } \\
\text { (g/day) }\end{array}$ & $1.03 \pm 0.45$ & $1.1 \pm 0.44$ & $0.94 \pm 0.45$ & 0.015 \\
\hline
\end{tabular}

In Group B, patients taking Amlodipine were having baseline readings mean SBP $155 \pm 14.43 \mathrm{mmHg}$, mean DBP was $103.54 \pm 7.78 \mathrm{mmHg}$ and mean MBP was $120.66 \pm 8.77$ $\mathrm{mmHg}$ and mean of HR was $76.69 \pm 3.11$ with statistically significant difference (Table 4).

Table 4: Intragroup comparison of group B (amlodipine): at baseline (0 week), 12 weeks and 24 weeks.

\begin{tabular}{|lllll|}
\hline Parameters & Baseline $(\mathbf{0}$ week) $($ Mean \pm SD $)$ & 12 weeks $($ Mean \pm SD) & 24 weeks $($ Mean \pm SD $)$ & p value \\
\hline SBP $(\mathrm{mmHg})$ & $155.25 \pm 14.43$ & $150.52 \pm 17.7$ & $145.79 \pm 12.36$ & 0.001 \\
\hline DBP $(\mathrm{mmHg})$ & $103.54 \pm 7.78$ & $91.91 \pm 7.78$ & $89.37 \pm 5.76$ & 0.001 \\
\hline MBP $(\mathrm{mmHg})$ & $120.66 \pm 8.77$ & $111.28 \pm 9.93$ & $108.18 \pm 7.04$ & 0.001 \\
\hline Mean HR & $76.69 \pm 3.11$ & $80.03 \pm 2.78$ & $80.03 \pm 2.78$ & 0.0001 \\
\hline Proteinuria (g/day) & $1.25 \pm 0.44$ & $1.1 \pm 0.44$ & $1.03 \pm 0.41$ & 0.015 \\
\hline
\end{tabular}

On comparing the effects of Amlodipine and Cilnidipine at 0 weeks we found that there was no significant difference in SBP, DBP, MBP, HR and proteinuria ( $p$ value $>0.05$ ) as shown in Table 5.

On comparing the effects of Amlodipine and Cilnidipine at 12 weeks we found that there was no significant difference in SBP, DBP, MBP, HR and proteinuria ( $\mathrm{p}$ value $>0.05$ ) as depicted in Table 6 .

On comparing the effects of Amlodipine and Cilnidipine at 24 weeks we found that there was no statistically significant difference in SBP, DBP, MBP and proteinuria ( $p$ value $>0.05$ ) (Table 7 ). As per safety profile of the study drugs cilnidipine and Amlodipine, both drugs were well tolerated by all patients. Three out of forty-eight patients taking cilnidipine reported nausea, vomiting, headache and dizziness and four out forty-six patients taking Amlodipine reported nausea, vomiting, headache, dizziness and ankle edema. There is no significant difference in adverse drug reaction in both of the drugs as shown in Table 8 .

\section{DISCUSSION}

Elevated blood pressure is an extremely common disorder affecting millions of populations in India and other countries. Although many of these individuals have no symptoms, chronic hypertension (either systolic or 
diastolic) can lead to cardiovascular accidents (strokes), congestive heart failure, myocardial infarction and renal damage. The incidence of morbidity and mortality significantly decrease when hypertension is diagnosed early and is properly treated. The goal of anti hypertensive therapy is to reduce cardiovascular and renal morbidity and mortality. The relationship between the blood pressure and the risk of cardiovascular event is continuous and thus lowering of even moderately elevated blood pressure significantly reduces cardiovascular disease and their complications. ${ }^{3}$

Table 5: Intergroup comparison of clinical parameters between amlodipine and cilnidipine groups: at 0 (baseline) week.

\begin{tabular}{|llll|}
\hline Parameters & $\begin{array}{l}\text { Cilnidipine } \\
(\mathbf{n}=48) \\
\text { Mean } \pm \text { SD }\end{array}$ & $\begin{array}{l}\text { Amlodipine } \\
(\mathbf{n = 4 6 )} \\
\text { Mean } \pm \text { SD }\end{array}$ & $\begin{array}{l}\mathbf{p} \\
\text { value }\end{array}$ \\
\hline $\begin{array}{l}\text { SBP } \\
(\mathrm{mmHg})\end{array}$ & $152.73 \pm 17.9$ & $155 \pm 14.43$ & 0.922 \\
\hline $\begin{array}{l}\mathrm{DBP} \\
(\mathrm{mmHg})\end{array}$ & $100.56 \pm 7.84$ & $103.54 \pm 7.78$ & 0.788 \\
\hline $\begin{array}{l}\mathrm{MBP} \\
(\mathrm{mmHg})\end{array}$ & $117.9 \pm 7.56$ & $120.66 \pm 8.77$ & 0.825 \\
\hline $\begin{array}{l}\text { Mean heart } \\
\text { rate }\end{array}$ & $78.60 \pm 3.29$ & $76.69 \pm 3.11$ & 0.676 \\
\hline $\begin{array}{l}\text { Proteinuria } \\
\text { (g/day) }\end{array}$ & $1.03 \pm 0.45$ & $1.25 \pm 0.44$ & 0.727 \\
\hline
\end{tabular}

Table 6: Intergroup comparison of clinical parameters between amlodipine and cilnidipine groups: at 12 weeks.

\begin{tabular}{|llll|}
\hline Parameters & $\begin{array}{l}\text { Cilnidipine } \\
(\mathbf{n = 4 8}) \\
\text { Mean } \pm \text { SD }\end{array}$ & $\begin{array}{l}\text { Amlodipine } \\
(\mathbf{n = 4 6}) \\
\text { Mean } \pm \text { SD }\end{array}$ & $\begin{array}{l}\mathbf{p} \\
\text { value }\end{array}$ \\
\hline $\begin{array}{l}\text { SBP } \\
(\mathrm{mmHg})\end{array}$ & $147.04 \pm 17.9$ & $150.52 \pm 17.74$ & 0.89 \\
\hline $\begin{array}{l}\mathrm{DBP} \\
(\mathrm{mmHg})\end{array}$ & $95.18 \pm 7.84$ & $91.91 \pm 7.78$ & 0.76 \\
\hline $\begin{array}{l}\text { MBP } \\
(\mathrm{mmHg})\end{array}$ & $113.63 \pm 7.56$ & $111.28 \pm 9.93$ & 0.88 \\
\hline $\begin{array}{l}\text { Mean heart } \\
\text { rate } \\
\text { (beats/min) }\end{array}$ & $74.27 \pm 3.48$ & $80.03 \pm 2.78$ & 0.20 \\
\hline $\begin{array}{l}\text { Proteinuria } \\
\text { (g/day) }\end{array}$ & $0.94 \pm 0.45$ & $1.1 \pm 0.44$ & 0.80 \\
\hline
\end{tabular}

The relevant biochemical parameters were noted down i.e. 24 hour urine protein, serum creatinine and blood urea nitrogen was $1.25 \pm 0.44 \mathrm{~g} /$ day. Group B, patients taking Amlodipine $10 \mathrm{mg}$, readings were noted down on 24 weeks biochemical parameters were noted down i.e. 24 hour urine protein, $1.03 \pm 0.41 \mathrm{~g} /$ day. Amlodipine and cilnidipine significantly reduced SBP, DBP, HR, MBP and proteinuria in our study. Similar results were seen in a study conducted by Hoshide $\mathrm{S}$ et al, to compare the effect of cilnidipine and Amlodipine on ambulatory BP. They did their study on 110 patients and performed 24 hour BP and heart rate monitoring before and after once daily use of cilnidipine and amlodipine. Both drugs reduced significantly clinic and 24 hour systolic and diastolic BP equally $(\mathrm{p}<0.005)$. Pulse rate was significantly reduced with cilnidipine. Author suggest N- type calcium channel blockade by cilnidipine may not cause reflex tachycardia and may be useful for the treatment of hypertension. ${ }^{9}$

Table 7: Intergroup comparison of clinical parameters between amlodipine and cilnidipine groups: at 24 weeks.

\begin{tabular}{|llll|}
\hline Parameters & $\begin{array}{l}\text { Cilnidipine } \\
(\mathbf{n = 4 6 )} \\
\text { Mean } \pm \text { SD }\end{array}$ & $\begin{array}{l}\text { Amlodipine } \\
(\mathbf{n = 4 8})\end{array}$ & $\begin{array}{l}\text { pean } \pm \text { SD } \\
\text { value }\end{array}$ \\
\hline $\begin{array}{l}\text { SBP } \\
(\mathrm{mmHg})\end{array}$ & $140.86 \pm 12.6$ & $145.79 \pm 12.36$ & 0.78 \\
\hline $\begin{array}{l}\mathrm{DBP} \\
(\mathrm{mmHg})\end{array}$ & $87.65 \pm 6.08$ & $89.37 \pm 5.76$ & 0.90 \\
\hline $\begin{array}{l}\mathrm{MBP} \\
(\mathrm{mmHg})\end{array}$ & $105.39 \pm 6.6$ & $108.18 \pm 7.04$ & 0.78 \\
\hline $\begin{array}{l}\text { Mean heart } \\
\text { rate } \\
\text { (beats/min) }\end{array}$ & 74.07 & $78.84 \pm 2.99$ & 0.30 \\
\hline $\begin{array}{l}\text { Proteinuria } \\
\text { (g/day) }\end{array}$ & $0.86 \pm 0.42$ & $1.03 \pm 0.41$ & 0.77 \\
\hline
\end{tabular}

Table 8: Adverse effects of cilnidipine and amlodipine.

\begin{tabular}{|lll|}
\hline Adverse effect & Cilnidipine & Amlodipine \\
\hline Nausea & 3 & 4 \\
\hline Vomiting & 3 & 4 \\
\hline Headache & 3 & 4 \\
\hline Ankle edema & 0 & 4 \\
\hline Dizziness & 3 & 4 \\
\hline
\end{tabular}

While comparing cilnidipine and amlodipine there was no significant difference seen in SBP, DBP, MBP and in both the groups at baseline i.e. 0 to 12 week, 12 to 24 weeks and 0 to 24 weeks. Cilnidipine caused decrease in heart rate at 0 to 12 week $(0.001), 12$ to 24(0.001) weeks and 0 to 24 weeks $(0.001)$. Amlodipine had increased heart rate from baseline to 12 weeks ( $\mathrm{p}=0.0001), 12$ to 24 weeks $(\mathrm{p}=0.051)$ and 0 to 24 weeks (0.001). No significant difference was seen in any other biochemical readings. My observations are in agreement to Sunichi Kojima et al, who did a study to compare Cilnidipine and Amlodipine Besilate. ${ }^{10}$ They took 28 patients in their study. Cilnidipine was given to 14 patients and other 14 patients were given Amlodipine. Author 's observations with cilnidipine at 0 week SBP (mmHg) was $135 \pm 5$, DBP $78 \pm 3$, MBP 97 \pm 3 , heart rate (beats per min) $75.6 \pm 3.2$ and proteinuria (g/day) $0.93 \pm 0.23$ at 24 weeks $\mathrm{SBP}(\mathrm{mmHg})$ was $133+5$, DBP $76 \pm 3, \mathrm{MBP}$ $95 \pm 3$, heart rate (beats per $\min$ ) $71.0 \pm 1.4$ and proteinuria (g/day) $0.84 \pm 0.18$. Cilnidipine had caused significant reduction of SBP, DBP, MBP, HR. In Amlodipine group observations were $\mathrm{SBP}(\mathrm{mmHg})$ was $141 \pm 4$, DBP $77 \pm 2$, MBP $99 \pm 2$, heart rate (beats per min) $76.9 \pm 1.7$ and 
proteinuria (g/day) $0.86 \pm 0.21$, at 24 weeks $\mathrm{SBP}(\mathrm{mmHg})$ was $139 \pm 4$, DBP $76 \pm 3$, MBP $97 \pm 2$, heart rate (beats per min) 74.6 \pm 2.0 . Amlodipine had caused significant reduction in SBP, DBP, MBP and heart rate from 0 to 24 weeks. Both the drugs had caused significant reduction of SBP, DBP, MBP and heart rate. Takahara, mentioned that a new generation $\mathrm{CCB}$ cilnidipine is having inhibitory action on the sympathetic $\mathrm{N}$ - type channel. ${ }^{11,12}$ Abe conducted a study to compare the effect of cilnidipine against those of Amlodipine on BP, albuminuria. In hypertensive patients with mild to moderate chronic kidney disease. ${ }^{13}$ After 48 weeks of treatment a significant and comparable reduction in systolic and diastolic BP in both the groups $(\mathrm{p}=<0.05)$.

Soeki reported the renoprotective and antioxidant effect of cilnidipine in hypertensive patients. ${ }^{14}$ They took 35 hypertensive patients. 18 patients were given cilnidipine and 17 patients were given amlodipine. After 24 weeks of treatment both the drugs reduced SBP and DBP without any significant difference within the groups. The urinary albumin to creatinine ratio decreased significantly in cilnidipine group $(\mathrm{p}=<0.05)$ as compared to Amlodipine group. Author suggests cilnidipine exerts a greater renoprotective effect through its antioxidant effect. Our observations are in comparison to that of author's observations as per regard to SBP and DBP. $(p=<0.001)$. this study is not in agreement with author's observations as regard to proteinuria as both the drugs cilnidipine and Amlodipine equally decreased proteinuria $(\mathrm{p}=<0.001)$.

Ando K did a study to compare the effect of L/ $\mathrm{N}$ type with L- type $\mathrm{CCB}$ in hypertensive patients with diabetes and microalbuminuria. ${ }^{15}$ Cilnidipine is more renoprotective than the L type CCB Amlodipine in patients with early stage. This study is in comparison to author's comparison cilnidipine at 0 week SBP 152.73 \pm 17.74 , mean DBP (diastolic) was $100.56 \pm 7.84 \mathrm{mmHg}$, mean MBP (mean blood pressure) was $118.1 \pm 7.56 \mathrm{mmHg}$ and mean of heart rate was $78.60 \pm 3.29$. readings were noted down at 12 weeks i.e. SBP $(\mathrm{mmHg}) 147.04 \pm 17.9 \mathrm{DBP}(\mathrm{mmHg})$ was $95.18 \pm 7.84$ and $\mathrm{MBP}(\mathrm{mmHg})$ was $113.63 \pm 7.56 \mathrm{mmHg}$ and mean of heart rate (beats per minute) was $74.27 \pm 3.48$. Readings were noted down at 24 weeks i.e. SBP $140.86 \pm 12.6$ DBP was $87.65 \pm 6.08$ and MBP was $105.39 \pm 6.6$ and mean of heart rate was 74.07 \pm 3.48 . A significant difference was observed in mean SBP, DBP, MBP, heart rate while comparing the pretreatment at baseline and after treatment at 12 weeks (p 0.001), at 12 to 24 weeks $(\mathrm{p}=0.001)$ and 0 to 24 weeks $(\mathrm{p}=0.001)$. Cilnidipine had shown anti sympathetic action. Author suggest that cilnidipine did not offer greater renoprotection than amlodipine, diabetic nephropathy.

\section{CONCLUSION}

No significant difference in SBP, DBP, MBP and proteinuria while comparing both the groups of patients taking cilnidipine and amlodipine at baseline i.e. 0 to 12 week, 12 to 24 weeks and 0 to 24 weeks. Cilnidipine caused decrease in HR 0 to 12 week (0.001), 12 to 24 weeks $(0.001)$ and 0 to 24 weeks $(0.0001)$. Amlodipine had increased heart rate from baseline to 12 weeks $(\mathrm{p}=0.0001)$, 12 to 24 weeks $(p=0.051)$ and 0 to 24 weeks $(0.001)$. No significant difference was seen in any biochemical readings.

Funding: No funding sources

Conflict of interest: None declared

Ethical approval: The study was approved by the Institutional Ethics Committee

\section{REFERENCES}

1. Chobanian AV, Bakris GL, Black HR. Seventh report of the Joint National Committee on Prevention, Detection, Evaluation, and Treatment of High Blood Pressure. Hypertension. 2003;42:1206-52.

2. Theodore AK, Hypertensive vascular disease, Longo DL, Fauci AS, Kasper DL, Hauser SL, Jameson JL, Loscalzo J editors. In: Harrison's Principles of Internal Medcine. $18^{\text {th }}$ Ed. McGraw-Hill; 2012:2042-2059.

3. Sever P, Beevers G, Bulpitt C. Management guidelines in essential hypertension: report of the second working party of the British Hypertension Society. BMJ. 1993;306:983-7.

4. James PA, Oparil S, Carter BL, Cushman WC, Dennison-Himmelfarb C, Handler J, et al. 2014 evidence-based guideline for the management of high blood pressure in adults: report from the panel members appointed to the Eighth Joint National Committee (JNC 8). JAMA. 2013:284-427.

5. Medicines adherence' (NICE clinical guideline 76, 2009). Available at: www.nice.org.uk/guidance/CG76 Bulletin of the World Health Organization, 2001, 79 (4).

6. SHEP Cooperative Research Group. Prevention of stroke by antihypertensive drug treatment in older persons with isolated systolic hypertension: final results of the Systolic Hypertension in the Elderly Program (SHEP). JAMA. 1991;265(24):3255-64.

7. Charles EA. The Kidney. In: Robbins, Kumar, Cotran editors. Robbins's pathologic basis of disease, $8^{\text {th }}$ Edition. Philadelphia, USA: W.B. Saunders; 2011:908-14.

8. Hoffman BB. Therapy of hypertension In: Brunton LL, Lazo JS, Parker KL editors. Goodman Gillman's The Pharmacological Basis of Therapeutics. 12 $2^{\text {th }}$ Edition. New York; McGraw Hill; 2012:845-868.

9. Hoshide S. Comparison of the effects of cilnidipine and amlodipine on ambulatory blood pressure. Hypertens Res. 2005;28:1003-8.

10. Kojima S, Shida M, Yokoyama H. Comparison between cilnidipine and amlodipine besilate with respect to proteinuria in hypertensive patients with renal diseases. Hypertens Res. 2004;27:379-85.

11. Takahara A, Iwasaki H, Nakamura Y, Sugiyama A. Cardiac effects of L/N-type $\mathrm{Ca}^{2+}$ channel blocker cilnidipine in anesthetized dogs. Eur J Pharmacol. 2007;565:166-70. 
12. Takahara A. Cilnidipine: a new generation ca channel blocker with inhibitory action on sympathetic neurotransmitter release. Cardiovasc Ther. 2009;27:124-39.

13. Abe M, Okada K, Maruyama N, Matsumoto S, Maruyama T, Fujita $\mathrm{T}$ et al. Benidipine reduces albuminuria and plasma aldosterone in mild-tomoderate stage chronic kidney disease with albuminuria. Hypertens Res. 2011;34:268-73.

14. Soeki T, Kitani M, Kusunose K, Yagi S, Taketani Y, Koshiba $\mathrm{K}$ et al. Renoprotective and antioxidant effects of cilnidipine in hypertensive patients. Hypertens Res. 2012;35:1058-62.

15. Ando K, Ueshima K, Tanaka S, Kosugi S, Sato T, Matsuoka $\mathrm{H}$ et al. Comparison of the Antialbuminuric
Effects of L-/N-type and L-type Calcium Channel Blockers in Hypertensive Patients with Diabetes and Microalbuminuria: The Study of Assessment for Kidney Function by Urinary Microalbumin in Randomized (SAKURA) Trial. Int J Med Sci. 2013;10:1209-16.

Cite this article as: Bala $\mathrm{R}$, Singh $\mathrm{H}$, Rupali, Verma $\mathrm{K}$. Role of antihypertensives drugs on proteinuria in patients with chronic kidney disease and hypertension. Int $\mathbf{J}$ Basic Clin Pharmacol 2017;6:2522-7. 